International Journal of Engineering \& Technology, $7(4.3)(2018) 519-523$
International Journal of Engineering \& Technology
SPC
Website: www.sciencepubco.com/index.php/IJET
Research paper

\title{
Intellectual Property as one of the Major Tendencies of Innovative Development of Railway Transport
}

\author{
Valeria Timanjuk $^{1 *}$, Yuliya Chernenko \\ ${ }^{1}$ Ukrainian Engineering and Pedagogical Academy, Kharkiv \\ *Corresponding author E-mail: timanjuk2010@gmail.com
}

\begin{abstract}
The paper deals with the issues of effective formation and use of intellectual property in the transport system with the example of a public joint-stock company "Ukrainian Railways" (UR). Within the framework of the reorganization of the UR structure it is proposed to create an "Intellectual Property Management Office", which forces are aimed at attracting the best scientific protectable designs and innovation projects, created both on the basis of their own enterprise and subject universities and organizations; the justification concerning the necessity of preparation of the patent policy is provided, which should correspond to the innovation strategy of the enterprise development; the economic-mathematical model is proposed, which allows to reach the optimum implementation of works that must be performed in accordance with the UR patent policy; the calculations of possible economic effects due to the commercialization of intellectual property objects are presented. It is substantiated that the use of intellectual property by the UR will enhance its image, competitiveness, become one of the tools of investment attraction, and will result in receiving additional profit.
\end{abstract}

Keywords: Economic effect; intellectual property management system; intellectual property; objects of intellectual property; OIP Commercialization; patent policy.

\section{Introduction}

Rail transport is one of the largest basic industries of the economy, the most important part of the industrial and social infrastructure, which accelerates the growth of the economy throughout the country. In recent years PJSC "Ukrainian Railways" (hereinafter referred to as UR) is experiencing a complex economic crisis and, as the analysis of numerous research publications shows, the main problems in the railway transport system are:

- on over $27 \%$ of trunk roads capital repair is overdue; depreciation of rolling stock fleet: electric trains $-84 \%$, locomotives $99 \%$, freight cars $-90 \%$, moral depreciation of railways and roadway;

- capacity limitations on important traffic flows;

- imperfection of tariff policy; fuel shortage;

- low level of normative-legal support;

- lack of a unified corporate governance system;

- low level of provision of transport services;

- insufficient level of competition in the market of transport services;

- ineffective implementation of quality management systems and compliance monitoring; low level of implementation of modern technologies and conduction of innovative policy in the field of rail transport;

- low level of implementation of energy saving technologies. As the positive aspect of the modern rail transport, it should be noted that UR provides 3\% of GDP of the country's economy. In a market economy, the railway brings substantial profits. In 2017, the company transferred tax money 15 billion UAH to the state, $58 \%$ of cargo turnover in the country is provided by rail transport, 4 out of 10 international transport corridors pass through Ukraine. The company employs more than 270,000 people, and it is the main employer of the country. There is currently a process of reforming the industry. An urgent problem is the withdrawal of the industry from the systemic crisis, the use of advanced innovative technologies and developments, and the improvement of management quality. Attention is drawn to the fact that none of the documents contains a state approach to the development of domestic production for the industry, the introduction of the achievements of science and technology, and the effective use of the objects of intellectual property (OIP) [1-4].

\section{Prerequisites for the Creation of a System for Managing Intellectual Property in Rail Transport}

Significant contribution to the industry's recovery from the crisis and the transition to an innovative way of development is to obtain additional income due to the unique competitive advantages acquired as a result of the use of intellectual property. The key role of intellectual property (IP) in the market conditions of management converges the views of many domestic and foreign scientists [5-17]. Despite the comprehensive study of the peculiarities and specificities of the IP, depending on the scientific directions, there are practically no work related to the IP management system in the transport industry, in which the methods and techniques for managing the formation, development and commercialization of intellectual assets are not considered, neither are considered the issues of development of the patent policy and strategy in UR. The purpose of these researches is to substantiate the expediency of creating, forming and effectively managing the exclusive rights to OIP due to the interests of innovative development of UR. In order to achieve the goal, it is necessary to introduce promising domestic results of innovation activity (RIA) by ensuring their legal protec- 
tion and the process of commercialization by developing an effective patent policy of UR, which will be implemented in accordance with the main strategy of the industry.

The structure of the company, its branches and sources that are capable of generating, accumulating innovative technical solutions were studied previously. The main sources of research and engineering and technical character are the Branch of "Research and Design and Technological Institute of Railway Transport" (hereinafter - the branch of RDTIRT) of PJSC UR. The branch consists of three structural subdivisions: the Kiev Design and Development Bureau of rolling stock; Poltava Design and Technology Bureau for the repair of locomotives; Dnipropetrovsk Research and Development Bureau of Road Transport.

The field of activity of the branch of RDTIRT merged a number of extremely important functions for the railway transport, connected with:

- carrying out scientific research, research and development works and development of normative documentation;

- analysis of the reliability of the technical condition of rolling stock and locomotives;

- control of the technical condition, and extension of the terms of service of the railway rolling stock, monitoring of the modernized and newly purchased rolling stock; carrying out measurements and tests of rolling stock and technical objects of in frastructure of railway transport, their components in a specific area of accreditation for compliance with the requirements of existing normative documents;

- development of new technologies, samples of materials and their tests in conditions on the railway transport with the organization of experimental production [1].

\section{Patent situation analysis}

A patent and information analysis of the research activities of organizations involved in the development of innovative technologies in transport and collaborating with UR was conducted, statistics on the number of patents for inventions, utility models, availability of advanced technologies that are ready for implementation, etc., were studied.

Table 1: The number of patents for technical developments in the field of rail transport

\begin{tabular}{|c|c|c|c|c|}
\hline Name of the organization & \multicolumn{3}{|c|}{ The amount of patents } \\
\cline { 2 - 5 } & $\mathbf{2 0 1 4}$ & $\mathbf{2 0 1 5}$ & $\mathbf{2 0 1 6}$ & $\mathbf{2 0 1 7}$ \\
\hline $\begin{array}{c}\text { 1. Pisarenko Institute of } \\
\text { Strength Problems of } \\
\text { the National Academy } \\
\text { of Sciences (IPMits) }\end{array}$ & - & 1 & 11 & 5 \\
\hline $\begin{array}{c}\text { 2. Dnipro National Universi- } \\
\text { ty of Railway } \\
\text { Transport of Ukraine } \\
\text { (DNEZ) }\end{array}$ & 59 & 37 & 28 & 51 \\
\hline $\begin{array}{c}\text { 3. Ukrainian State Universi- } \\
\text { ty of Railway } \\
\text { Transport (UkrDUZT) }\end{array}$ & 29 & 14 & 16 & 18 \\
\hline $\begin{array}{c}\text { 4. Ukrainian Research Insti- } \\
\text { tute of Wagon Build- } \\
\text { ing (UkrNIIV) }\end{array}$ & - & - & 3 & 1 \\
\hline
\end{tabular}

The table does not include patents of the Scientific and Technical Complex "E.O. Paton Institute of Electric Welding" of the National Academy of Sciences of Ukraine, since it was not possible to identify the patents that are related to the railway. These may be patented technologies that are related to technical diagnosis and non-destructive control that may be relevant to the safety of the rail transport. The great experience dealing with OIP has the V. Dahl Eastern Ukrainian National University. The University is the patent holder of over 2000 patents, including 175 foreign patents in the United States, France, Canada, Germany, and others.
In its database there are 255 patents related to the railway, among which there are only 57 patents for utility models and 1 patent for the invention. In the statistical patent information, four valid patents were found: 1 for the utility model and three for the inventions of the State Economic-Technological University of Transport, which belong to the carriage-building industry. Among the organizations analyzed, the most inventive activity origins from DNEZ. For the period of time from 2004 to 2017, the university has 623 patents, for 2014-2017, there are 175 patents, but among them are only 7 valid patents for inventions. The largest number of inventions and utility models are created in higher educational institutions, and the least - academic institutions and design organizations.

The preliminary analysis allows us to conclude that the crisis trends in the Ukrainian economy have an adverse effect on the innovation activity of each enterprise, organizations reduce the number of applications for inventions and, first of all, due to lack of own funds and the possibility of creating at least prototype models, lack of intellectual property market, lack of qualified IP management specialists.

Taking into account the role and significance of IP in market conditions, UR can take the following important steps to improve its competitive position by attracting OIP into the economic turnover

\section{Creating an Office of Intellectual Property Management}

At present, UR is an integrated corporate structure (ICS), which consists of a set of enterprises, some of which are capable of creating a different type of OIP. In this case, the issues of IP management become relevant. The strategic goal of such a structure is to increase the level of novelty and competitiveness of new transport system objects. "The Office of Intellectual Property Management" should be included in the ICS, which will take key decisions on the creation, accumulation, formation and commercialization of OIP rights, and promote the regulation of the relationship between IP subjects, to pay rewards to authors and facilitators of IP. The scheme of ICS interaction in the field of IP management is presented in Fig. 1.

Creation of the office will allow to develop a unified patent policy and long-term patent strategy, develop a normative base for ensuring the process of intellectual activity in the legal field, to direct efforts to solve the urgent problems of the industry. Particular attention should be paid to the formation of a patent-information database. It should be built on the basis of modern information technology, such as the use of blockchain. Blokchain is a chain of blocks containing all the necessary data: on subjects and objects of IP, agreements, contracts, license agreements, transactions, etc. [8]. The use of blockade technology in the management of IP has the following benefits: public availability to the information of all participants in the process; impossibility to modify and correct data; reliability and data security; transparency and the ability to control the passage of information; granting of the right to use IP, continuous replenishment of data; exclusion of intermediaries, etc. 


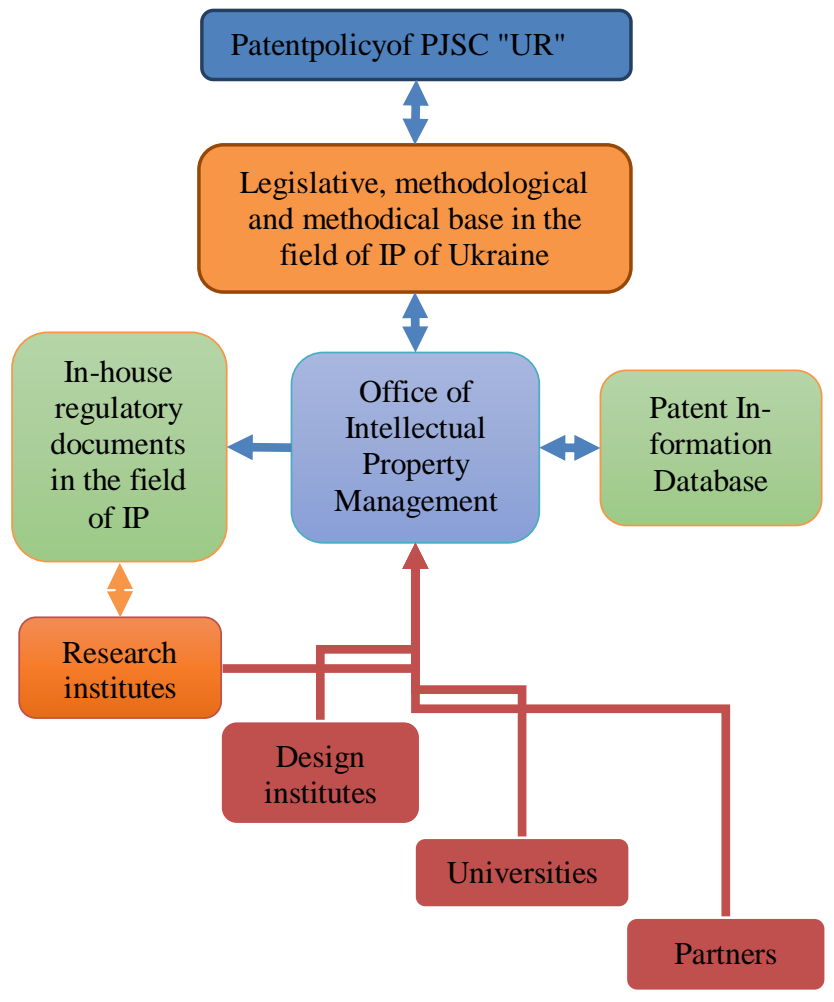

Fig. 1: Flowchart of intellectual property management system in UR.

In order to consolidate the rights to OIP and create a system of document circulation, it is necessary to develop internallyregistered regulatory documents in the field of IP and their list, which includes:

- Patent for invention.

- Patent for utility model.

- Patent for industrial design.

- Certificate of Trademark.

- Certificate of service.

- Certificate of official registration of programs for electronic computing machines (ECM)

- Certificate of official registration of copyrights for works.

- Duplicate of security document.

- Contract of the transfer of the invention patent.

- Patent transfer contract for the utility model.

- Patent transfer contract for industrial sample.

- Contract of the transfer of the trademark.

- Contract of the transfer of service.

- Authorship Agreement on Transfer of Exclusive Rights.

- Agreement on the full transfer of all proprietary rights to the regis tered program for the ECM.

- Agreement on the full transfer of all property rights to the registered database.

- License agreement on the submission of the right to use the invention.

- License agreement on the submission of the right to use a utility model.

- License agreement on the submission of the right to use an industrial sample.

- License agreement on the submission of the right to use the trademark.

- License agreement on the submission of the right to use the service mark.

- The author's agreement on the transfer of non-exclusive rights.

- Agreement on the transfer of authority on the collective management of property rights.

- Agreement to provide the one that manages the rights on a collective basis of the organization of the right to use copyright objects.
- Agreement on the transfer of property rights of a registered ECM.

- Agreement on the transfer of property rights of the registered database.

- Constituent documents, namely, statutes and founding treaties, concluded and signed by the founders and registered with the respective registration authorities in accordance with the current legislation.

- Documents related to the performance of research, development and technological works.

- Author's order contract.

- Contract for research work.

- Contract for research and development works.

- Contract for the performance of technological works.

- Contract for development and technological works.

- Contract for research, developmental and technological works.

- Agreement on the transfer of scientific and technical products.

- Acceptance certificate of an intangible asset.

- Act of disposal of intangible assets.

- Act of writing off an intangible asset.

- Patent Study Report.

- Reporting documents on the implementation of research, developmental and technological works.

- Employment contract with the employee concluded by the organization performing the functions of the employer.

- Duty assignment of the employee from the employer organization.

- Employment contract of an organization with a specialist involved to perform tasks specified in the contract.

This list of documents is developed on the basis of the legislative and regulatory framework in the field of IP of Ukraine and is an official confirmation of the availability and use of IP without violating intellectual property rights, creating a business IP, alienating IP, accounting for intangible assets [9]. The composition and completion of the required documents is carried out in dependence of the tasks set in accordance with the patent policy. The prerogative of such an office is that it is possible to apply a systematic approach to IP management, create the preconditions for achieving a synergistic effect in the commercialization of IP, purposefully direct all efforts to achieve the overall corporate goal.

Thus, the IP management system in the UR is an organizational, economic, legal, coordinating and analytical activity carried out on the basis of patent policy and within the framework of the general innovation strategy of UR. IP management should be conducted in a few stages: initially, OIP is detected and registered in the patent departments of the organization where it was created, then, along with the description and proposal about the registration of its rights, it is sent to the head office of the corporation. According to -the patent policy of the enterprise, this IP is transformed into a general "patent portfolio", examining forms, types, goals, evaluating the value of rights to OIP and the efficiency of innovations. Obtaining a security document has such objectives as confirmation of the legitimacy of the object of IP rights, global novelty, the possibility of commercialization and protection of IP from offenders, counterfeit products, copying.

\section{Development of the Patent Policy of PJSC "UR"}

Development of a patent policy of an enterprise is a rather complex and time-consuming process. Patent policy defines the official legal position of the enterprise. In this article, we list only its main directions which should be reflected in this document.

1. General provisions. This part of the document highlights what the IP is meant to provide, what it is aimed at, how the relations on the issues of creation, protection and use of RIA and OIP are regulated, timing and definitions are given. 
2. The main goals, objectives, principles of the patent policy. This section should be formulated neatly, clearly, transparently, so that the management is convinced of the need to implement measures in accordance with this document.

3. Mechanism of organization of innovation process using OIP. The section highlights the most important technical directions that should be protected by legal protection.

4. The order of disposal of the exclusive rights belonging to the corporation. Describes how the rights between the subjects of the IP will be allocated and fixed.

5. Measures concerning the use the rights to OIP. Describes the process of managing IP rights from their creation to commercialization.

6. Resource support for patent policy. The following resources are provided for the implementation of the patent policy: financial, informational, intellectual, legal and regulatory.

7. Results. It is necessary to develop and bring those indicators by means of which it is possible to judge the implementation of the patent policy. Also, a system of indicators of the efficiency of the implementation of the patent policy should be developed. 8. Stages of the implementation of the patent policy. As a result, the phase should be consistent with the core strategy of the corporation and ensure the formation of a corporate mechanism for the commercialization and use of RIA, which are provided with legal protection.

Patent policy is the basis to the further development of a patent strategy, a step-by-step program of work related to the creation, formation and implementation of an IP or a roadmap.

\section{Designing the "Office of the IP Manage- ment" System with the Optimal Result}

The solution of this problem is proposed to be carried out on the basis of the principles of forming the criteria of optimality of innovative complex organizational and technological systems, which may include the project "Office of the IP Management" [10].

In order to substantiate the feasibility and optimality of the implementation of the patent policy program and design of the "Office of the IP Management", it is necessary to choose the design criteria of optimality. It must strictly correspond to the purpose that should be achieved as a result of the operation of the project and the selected performance indicators.

The purpose of the project is to effectively manage the IP and generate additional profit from the use of OIP. Thus, the efficiency indicator is equivalent to the goal set.

The optimality criterion is a quantitative measure that establishes the correspondence between the level of achievement of the goal as a result of the operation of the "Office of the IP Management" and the chosen efficiency indicator.

Thus, it is possible to determine the composition of the project that has the maximum generalized effect, under conditions that the costs of creating and using the elements of the project systems will not exceed the allocated amount, and the project implementation time will not exceed the planned one.

$D\left(O_{0}\right)=\max D\left(\varphi_{i}\right)$

$Z=\sum_{n=1}^{n} K_{d} Z_{n}\left(C_{i n} U_{p n}\right) \leq Z_{0^{n}} T \leq T_{0}$,

Where D-performance indicator;

$O_{0}$-optimal option;

$\varphi_{\mathrm{i}}$-amount of the work performed;

$\mathrm{Z}_{\mathrm{p}}$-the given value of the amount of expenses for the creation and operation of the system;

Z-total costs;

$\mathrm{K}_{\mathrm{d}}$-the coefficient of bringing costs to one point of time;

$\mathrm{Z}_{\mathrm{n}}$-the amount of money spent on the project for the considered sub-period of the project;
$\mathrm{C}_{\mathrm{in}}-$ the number of basic elements of the $\mathrm{i}$-th type that must be created for the $\mathrm{n}$-th period considered;

$U_{p n}$-composition of the auxiliary elements of the p-type, introduced for the current $\mathrm{n}$ period of the program;

$\mathrm{T}$-amount of time needed to create a project;

$\mathrm{T}_{0}$-deadline of system status.

The generalized function of the project's performance indicator is determined by national, regional and sectoral terms and may take the form of a "weighted sum" of the scope of work performed by the project.

$D=\sum_{j=1}^{n} B_{j}-\varphi_{j}$,

Where $B_{j}$ - the coefficient that takes into account the importance of the $\mathrm{j}$ type work.

Sums of squares of the deviation of the volume of work performed from the given values (taking into account the rating of the importance of works):

$D=\sum_{j=1}^{n} B_{j} \cdot\left(B_{j}^{0}-\varphi_{j}\right)^{2}$,

Where $B_{j}^{0}$-the volume set.

As a generalized function of efficiency can be taken: "weighted" total profit for a certain period; payback period of total expenses.

The given model allows to consider factors which are important for the effective functioning of the project, for example: simultaneous carrying out of works in different subsystems of the project, change in the amount of executed works; specific needs in the personnel, retraining of personnel, resources, information technologies, etc. specifies the scope of work, etc.

As expenses, the expenses for the creation and use of OIP; labor costs and royalties; material expenses, etc. are taken into account.

As a possible effect needed to be taken into account while solving this problem, one should distinguish: the effect of the growth of the price of the final product; the effect of reducing the cost of using OIP; integral effect of use of IP, etc.

It should also highlight the main stages of the work to achieve effective work.

Thus, for the construction of an economic-mathematical model, it is important to allocate the so-called cost-effectiveness criterion.

\section{Acquiring an Integrated Economic Effect}

Also, for the evaluation of the effectiveness of the intellectual property management system, requires to use the well-known approaches, principles and methods of estimating IP that allow calculating the integral effect of the use and commercialization of OIP [5-7, 9-17]. Calculations are summarized in table 2.

Table 2: Integral economic effect of using IP

\begin{tabular}{|c|c|}
\hline $\begin{array}{c}\text { Determine the effect depending } \\
\text { on the nature of the use of } \\
\text { OP, the cost of OP }\end{array}$ & Notation keys, sources \\
\hline $\begin{array}{l}\text { The economic effect from the } \\
\text { benefits of the profit: } \\
\mathbf{E}_{1}=\sum_{\mathrm{t}=1}^{\mathbf{I}} \mathbf{V}_{\mathrm{t}}-\Delta \mathbf{P}-\mathbf{C}_{\mathrm{d}}\end{array}$ & $\begin{array}{l}\nabla_{\mathrm{t}}-\text { output with using IP in the } \\
\quad \text { year } \mathrm{t} \text {; } \\
\Delta \mathrm{P} \text { - advantage in profit; } \\
\mathrm{C}_{\mathrm{d}} \text { - coefficient of discounting. }\end{array}$ \\
\hline $\begin{array}{l}\text { The economic effect from win- } \\
\text { ning the prime cost: } \\
\mathrm{E}_{2}=\sum_{\mathrm{t}=1}^{1} \mathrm{~V}_{\mathrm{t}}-\Delta \mathrm{E}_{\mathrm{t}}-\mathrm{C}\end{array}$ & $\begin{array}{c}\Delta \mathrm{E}_{\mathrm{t}}-\text { saving on expenses while } \\
\text { using OIP in year } \mathrm{t} .\end{array}$ \\
\hline $\begin{array}{l}\text { The economic effect from selling } \\
\text { a license based on royalty: }\end{array}$ & $\begin{array}{l}\nabla_{t}-\text { output while using OIP in } \\
\quad \text { year } t \text {; } \\
\mathbb{P}_{t}-\text { sales price per unit of output }\end{array}$ \\
\hline
\end{tabular}




\begin{tabular}{|c|c|}
\hline $\begin{array}{c}\text { Determine the effect depending } \\
\text { on the nature of the use of } \\
\text { OP, the cost of OP }\end{array}$ & Notation keys, sources \\
\hline $\mathrm{V}_{\mathrm{t}}-\boldsymbol{P}_{\mathrm{t}}-\mathrm{R}_{\mathrm{t}}-\mathrm{C}_{\mathrm{d}}$ & $\begin{array}{l}\quad \text { using OIP in year } t ; \\
\mathbb{R}_{\mathrm{t}}-\text { royalty rates in year } \mathrm{t} \\
\mathrm{T}-\text { the term of contract signing; } \\
\mathrm{C}_{\mathrm{d}}-\text { coefficient of discounting. }\end{array}$ \\
\hline $\begin{array}{l}\text { The economic effect of using OIs } \\
\text { as intangible assets: } \\
\qquad \mathbf{E}_{4}=\mathbb{I}_{\mathrm{ut}}+\mathrm{A}_{\mathrm{t}}\end{array}$ & $\begin{array}{l}\mathbb{P}_{\mathrm{ut}}-\text { expected net profit remain- } \\
\text { ing at the disposal of the en- } \\
\text { terprise at the expense of } \\
\text { products using OIP in year } \\
\mathrm{t} \text {; } \\
\mathrm{A}_{\mathrm{t}}-\text { depreciation in year } \mathrm{t} \text {. }\end{array}$ \\
\hline $\begin{array}{c}\text { General expenses on OIP: } \\
\mathrm{E}=\mathrm{E}_{\mathrm{d}_{1}}+\mathrm{E}_{\mathrm{p}_{2}}+\mathrm{E}_{\mathrm{M}_{3}}+\mathrm{E}_{\mathrm{lc}_{4}}+ \\
+3 \mathrm{me}_{\mathrm{g}} \\
\text { (Planned costs are discounted) }\end{array}$ & 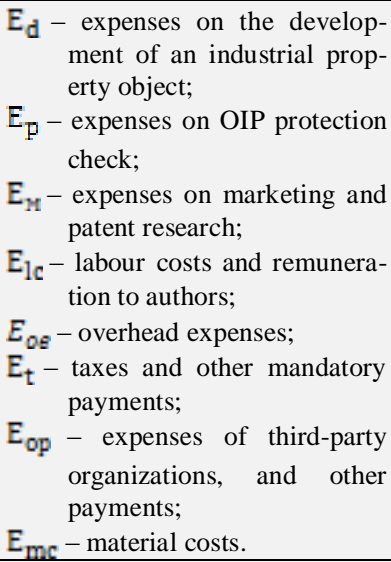 \\
\hline \multicolumn{2}{|c|}{ Result or integral economic effect } \\
\hline
\end{tabular}

This chart takes into account the economic effects that can be obtained in the most common operations in the use of OIP. An integral economic effect allows us to assess the effectiveness of the IP management system.

\section{Conclusions}

Creating, during the reform of the leading industry in the ICS "UR", the "Office of Intellectual Property Management", will allow to professionally and purposefully concentrate all promising scientific and technological developments and manage the IP in one innovatively organized system. The use of IP is an important economic tool in accelerating the emergence of highly effective technologies, the development of the main scientific and technological directions of the innovation transport system. IP contributes to increasing the competitiveness of manufactured goods and services, provides image, economic security and business reputation, and it is a powerful tool for attracting investment.

\section{References}

[1] Sciencendktiuz [Electronic resource], available online: https://www.uz.gov.ua/about/activity/science/ndkti_uz

[2] last visit: 21.06 .2018

[3] Beketov Yu.A. (2005) «Problems of strategic development of transport enterprises in the conditions of transitional economy», Bulletin of Kharkov National Automobile and Highway University, available online: http://cyberleninka.ru/article/n/problemystrategicheskogo-razvitiya-transportnyh-predpriyatiy-vusloviyahperehodnoy-ekonomiki.

[4] Results of Transport of Ukraine for 2017 [Electronic resource], available online: http://www.ukrstat.gov.ua/

[5] Chilikin K.P. (2015) «Protection of intellectual property of logistics companies») Young Scientist, № 8, 766-771, available online: https://moluch.ru/archive/88/17500/ last visit: 21.06.2018.
[6] 'Lazarev M. I., Ruban N. P., and Timanyuk M. H., (2017) Patent and Copyright. Educational manual Forms of teaching. All specialty, Ukr.Ing.Pad.Acc.

[7] Armensky A.E. (2009) «Innovative economy and the role of intellectual property in it», Innovations, N 11, 30-33.

[8] Mukhopad V. I. (2010), Commercialization of intellectual property. Moscow: Magistr-Infra-M.

[9] Swan M. Blockchain (2017) Scheme of the new economy. M : Olimp-business.

[10] Timanyuk Valeria Nikolaevna (2007) «Management of the processes of commercialization of intellectual property in the pharmaceutical industry: diss. Candidate of Pharmaceutical Sciences: 15.00.01, National Pharmaceutical University, Kh., 143-160.

[11] Akimov A.A. (2002) Systemological bases of innovation, SPb .: Politechnika, 256 - 266.

[12] Krainev P.P., (2004) Intellectual economy: management of industrial property, Monograph, K.: Concern Publishing House "In Yure".

[13] Fedulova L. "Trends in the formation of the latest technological structure in the global economy: the role of intellectual property management”, Economy of Ukraine, № 122011, 23-35.

[14] Appraisal of Intellectual Property Rights, (2007), National Standard No 4, approved by the Resolution of the Cabinet of Ministers of Ukraine dated October 3, 2007, No. 1185, Uriadovy Courier, 2007, No. 191, October 17

[15] Methodology for appraisal of property rights of intellectual property 2008-08-16, approved by order of the State Property Fund of Ukraine 25.06.2008 N 740 .

[16] Butnik-Siverskyi, O. (2011) «The economic and legal problems of providing valuation and accounting of proprietary rights of intellectual property», Law of Ukraine, No. 3, 149-158.

[17] European Commission. Final Report from the Expert Group on Intellectual Property Valuation Luxembourg: Publications Office of the European Union (2014) available online: https://ec.europa.eu/research/innovationunion/pdf/Expert_Group_Report_on_Intellectual_Property_Valuation _IP_web_2.pdf

[18] Lagrost, C., D. Martin, C. Dubois and S. Quazzotti (2010), "Intellectual property valuation: how to approach the selection of an appropriate valuation method", Journal of Intellectual Capital, vol. 11 n. 4, , Emerald Group Publishing Limited. 